Abstracta Iranicanica

Revue bibliographique pour le domaine irano-aryen

Volume 27 | 2006

Comptes rendus des publications de 2004

\title{
"Le monnayage sidonien de Mazday ». Transeuphratène, 27 (2004), pp. 155-162.
}

\section{Astrid Nunn}

\section{(2) OpenEdition}

1 Journals

\section{Édition électronique}

URL : http://journals.openedition.org/abstractairanica/5705

DOI : 10.4000/abstractairanica.5705

ISSN : 1961-960X

Éditeur :

CNRS (UMR 7528 Mondes iraniens et indiens), Éditions de l'IFRI

\section{Édition imprimée}

Date de publication : 15 mai 2006

ISSN : 0240-8910

\section{Référence électronique}

Astrid Nunn, « «Le monnayage sidonien de Mazday ». Transeuphratène, 27 (2004), pp. 155-162. », Abstracta Iranica [En ligne], Volume 27 | 2006, document 72, mis en ligne le 02 janvier 2007, consulté le 25 septembre 2020. URL : http://journals.openedition.org/abstractairanica/5705 ; DOI : https:// doi.org/10.4000/abstractairanica.5705

Ce document a été généré automatiquement le 25 septembre 2020.

Tous droits réservés 


\section{« Le monnayage sidonien de Mazday ». Transeuphratène, 27 (2004), pp. 155-162.}

\section{Astrid Nunn}

1 Les deux grands spécialistes de numismatique phénicienne s'attaquent ici non aux monnaies d'une ville mais à celles d'une personne. Mazday a en effet frappé des monnaies à Tarse, Sidon et Babylone. Il fut au service de quatre rois perses et d'Alexandre le Grand entre 360 et après 331. Les AA. datent les monnaies de Sidon, tout en expliquant pourquoi Mazday avait choisi cette ville pour son monnayage. Il fallait surveiller de près cette cité rebelle et elle était peut-être la capitale de la satrapie de Transeuphratène au moment requis. En s'occupant des monnaies les AA. retracent la vie de Mazday.

\section{INDEX}

Thèmes : 3.2.1. Elam

\section{AUTEURS}

ASTRID NUNN

Université de Munich 